\title{
PENERAPAN MANAJEMEN KONFLIK BERBASIS SEKOLAH STUDI KASUS DI DUA SEKOLAH
}

\author{
Siti Nurnisa Dewanta, Udik Budi Wibowo \\ Yayasan Budi Mulia Dua Yogyakarta, Universitas Negeri Yogyakarta \\ siti_nurnisa@yahoo.com, yube2u@yahoo.com
}

\begin{abstract}
Abstrak
Tujuan penelitian ini: (1) mengenali bentuk konflik di sekolah, (2) mengetahui bagaimana sekolah mengelola konflik. Penelitian ini menggunakan pendekatan kualitatif dan metode studi kasus. Teknik dalam pengumpulan data: menggunakan penelusuran dokumen, arsip, wawancara, dan observasi partisipan. Wawancara dengan kepala sekolah, wakil kepala sekolah, guru-guru, peserta didik, dan alumni. Pengamatan langsung dilakukan untuk mendalami manajemen konflik di setiap sekolah. Hasil penelitian: (1) konflik yang terjadi diantara para peserta didik, individu atau kelompok bisa berwujud bullying, perkelahian atau tawuran. (2) konflik yang terjadi antara peserta didik disebabkan perbedaan persepsi, tujuan dan ketergantungan antara mereka. (3) konflik antara peserta didik - guru berwujud sikap tidak sopan, mengabaikan pelajaran, ancaman fisik terhadap guru. (4) konflik antara guru - peserta didik, karena ketidaksiapan guru menerima sikap kritis, serta ketidaksamaan persepsi dan tujuan. (5) kekolah menyelesaikan konflik dengan cara: mendatangkan tokoh, menciptakan konflik baru, penerapan progam-program sekolah untuk membangun komitmen, komunikasi yang terbuka dan keakraban satu sama lain. (6) untuk menyelesaikan konflik, guru harus membangun komunikasi \& keakraban dengan peserta didik, memudahkan penyelesaian konflik diantara mereka.
\end{abstract}

Kata kunci: konflik, resolusi konflik, manajemen konflik berbasis sekolah

\section{THE APPLICATION OF SCHOOL CONFLICT MANAGEMENT CASE STUDY IN TWO SCHOOLS}

\begin{abstract}
The purpose of this study are. (1) knowing the forms of conflicts (2) how the schools manage the conflicts. This was a qualitative study employing a case study method. The data were collected through tracing documents, interviewing students, principals, alumni and teachers, and observe participants. The results are. (1) the conflicts among students in the form of bullying, quarrels and fights. (2) the conflicts among students result from different perceptions, goals, and dependence. (3) the conflicts occurring between students and teachers in the form of students' impolite, negligance of lessons, physical attacks to the teachers. (4) the conflicts between teachers and students may occur because of teachers are not ready to accept students' critical attitudes, and the difference in the perceptions and goals. (5) school has resolved the conflicts in some ways: using figures, making new conflict, applying programs to build commitment, good communication and relationship. (6) teachers have to build good communication and relationship with the students.
\end{abstract}

Keywords: conflict, conflict resolution, school-based conflict management 


\section{Pendahuluan}

Perkelahian peserta didik terjadi di beberapa kota seperti Jakarta, Surabaya, Medan dan Yogyakarta. Data perkelahian peserta didik di Jakarta dari Bimmas Polri Metro Jaya, tahun 1998 terdapat 230 kasus yang menewaskan 15 peserta didik, 2 anggota Polri; tahun 1999 meningkat dengan 37 korban meninggal.

Berdasarkan data Bimmas Polri Metro Jaya pada tahun 2010, setidaknya terjadi 128 kasus tawuran antar peserta didik. Pada 2011, terjadi 330 tawuran yang menewaskan 82 peserta didik. Angka itu melonjak tajam lebih dari 100\% dibandingkan yang terjadi pada tahun 2010. Pada 2012 terjadi 139 tawuran, menewaskan 12 peserta didik (Litbang TV One, 27 September 2012). Jumlah perkelahian dan korban cenderung meningkat dari tahun ke tahun, bahkan dalam satu hari terdapat sampai tiga perkelahian di tiga tempat sekaligus (KPAI, 15 Mei 2012).

Jumlah tawuran peserta didik yang meningkat dari tahun ke tahun tidak hanya dalam jumlah, melainkan juga tingkat kekerasan dimana mereka menggunakan senjata tajam. Selain jumlah dan tingkat kekerasan, yang memprihatinkan juga adalah bahwa tawuran pelajar sudah terjadi hampir di semua wilayah (kota besar, kota kecil dan pedesaan), dan pada tingkatan sekolah SMP.

Lebih memprihatinkan lagi, sekolah adalah salah satu penyebab terjadinya tawuran, disamping keluarga dan masyarakat. Bullying hampir setiap saat terjadi di sekolah. Bullying berupa sikap kekerasan fisik dan/atau verbal yang dilakukan oleh kakak kelas terhadap adik kelas terkadang tidak hanya terjadi di masa orientasi, melainkan berlanjut dalam kegiatan pembelajaran selanjutnya. Kakak kelas yang menjadi panitia pelaksana MOPD merasa seakan-akan memiliki kekuasaan yang terus berlanjut sampai mereka lulus.

Konflik terjadi juga antara guru dengan peserta didik. Guru terkadang lebih berperan sebagai pelaksana peraturan dan "pemegang cambuk hukuman" daripada menjadi pemberi pemahaman, pe- ngarahan dan pujian. Sebagai pelaksana peraturan, guru lebih mudah memberikan hukuman kepada peserta didik yang tidak mengerjakan PR, terlambat masuk kelas, tidak mengenakan seragam dan terkadang hanya sekedar tidak bisa menjawab pertanyaan. Wujud kekerasan yang dilakukan oleh guru mungkin tidak/atau kurang disadari memberi dampak negatif adalah kekerasan verbal.

Kekerasan dari orang dewasa amat menekan perasaan, membuat anak merasa sakit hati, dendam dan marah. Menurut hasil penelitian dari Yayasan SEJIWA pada tahun 2010, semua anak yang terlibat dalam penelitian mengaku merasa sedih, tertekan, takut, malu, marah serta tidak berdaya menghadapi kekerasan baik dari guru, orang tua maupun teman sebaya.

Sekolah perlu memikirkan cara-cara yang menarik dan menyenangkan dalam penyampaian materi pembelajaran dan proses belajar mengajar, dan bukan sekedar fokus memikirkan materi atau subtansi pembelajaran saja. Cara guru mengelola kelas, menyampaikan materi, bersikap dan bertutur kata perlu diajarkan dengan caracara yang menyenangkan. Guru harus menyadari bahwa dia menjadi pusat perhatian ketika di kelas, sehingga dia harus tampil dan mengelola kelas dengan cara yang menarik dan menyenangkan, terutama pada mata pelajaran-mata pelajaran utama. "Sebaik apa pun kurikulumnya, sulit berhasil apabila tidak dijalankan dengan strategi pembelajaran yang menarik dan menyenangkan bagi peserta didik" (Chatib, 2009, p.110).

Peraturan atau tata tertib sekolah seringkali diterapkan secara tidak relevan. Sebagai misal, sekolah lebih mengutamakan perhatian kepada peserta didik dalam pemakaian emblem pada seragam sekolah dibandingkan dengan menangani peserta didik yang melakukan bullying. Beberapa peraturan dan konsekuensi peraturan yang diberikan kepada peserta didik tidak memberikan pemahaman efek jera, namun yang dirasakan adalah rasa malu dan dendam. Beberapa sekolah menerapkan peraturan bahwa bagi peserta didik yang 
terlambat, tidak diperbolehkan memasuki sekolah dan gerbang sekolah sudah ditutup. Konsekuensi dari peraturan ini adalah, tidak jarang terjadi pemandangan bahwa terdapat satu dua peserta didik atau lebih yang menunggu di depan gerbang sekolah tanpa melakukan kegiatan yang bermanfaat.

Bisakah sekolah menjadi tempat bagi peserta didik mempelajari bagaimana menyelesaikan masalah dengan cara damai? Apakah praktik dan tradisi bertengkar, tawuran, penerapan aturan disiplin yang ketat, serta bullying dapat dihilangkan dari lingkungan sekolah? (Panggabean, Media Indonesia, 2 Juni 2008). Pertanyaan di atas, sangat memungkinan untuk dijawab dengan kata "bisa". Secara prinsip, sekolah adalah lembaga yang memiliki otonomi, legalitas dan sistem untuk menata anggota organisasinya.

Anggota organisasi sekolah adalah kepala sekolah, peserta didik, pendidik, tenaga kependidikan, stake holder yang satu sama lain berinteraksi setiap hari. Interaksi mereka tidak jarang menimbulkan konflikkonflik. Burke (Deutsch, 2006, p.782) menyatakan bahwa onflik dalam organisasi terbagi dalam empat bentuk: konflik individu, konflik antar individu, konflik antar kelompok, konflik antar organisasi.

Penelitian ini dilakukan di SMAN 6 Yogyakarta dan SMA Kolese de Britto Yogyakarta. Alasan memilih SMAN 6 dan SMA Kolese de Britto, karena kedua sekolah tersebut memiliki usia yang sudah lama serta masing-masing mewakili sekolah swasta dan sekolah negeri. SMAN 6 dikenal sebagai "sekolah geng" pada era tahun 1994-2004. SMA Kolese de Britto adalah sekolah khusus putera yang pernah melakukan perkelahian.

\section{Metode Penelitian}

Jenis Penelitian

Penelitian ini mengunakan metode penelitian kualitatif - studi kasus. Metode ini digunakan untuk mendapatkan gambaran tentang mengapa dan bagaimana konflik terjadi di SMA Negeri 6 Yogyakarta dan SMA Kolese de Britto Yogyakarta.
Waktu pelaksanaan penelitian

Penelitian ini, dilaksanakan mulai bulan Nopember 2012 hingga September 2013. Tahapan-tahapan prosedur yang dilakukan dengan tahapan observasi lapangan dan wawancara langsung, wawancara melalui telpon, sms dan email juga penelusuran dokumentasi.

Target/Subjek Penelitian

Subjek penelitian: Kepala Sekolah atau Wakil Kepala Sekolah, guru, peserta didik, alumni. Kepala sekolah atau Wakil Kepala Sekolah sebagai pimpinan yang mengetahui dan mengelola semua kebijakan sekolah. Guru, aktor yang berinteraksi dengan peserta didik. Peserta didik, alumni sebagai pelaku yang terkena kebijakan sekolah.

Prosedur

Teknik pengumpulan data dalam penelitian ini melibatkan tiga jenis strategi. (1) pengamatan/observasi, untuk mengamati perilaku dan aktifitas di lokasi penelitian. (2) wawancara terhadap Kepala Sekolah, Wakil Kepala Sekolah, guru, peserta didik dan alumni. Wawancara digunakan untuk memperoleh data tentang apa bentuk-bentuk konflik yang terjadi, mengapa konflik terjadi di sekolah dan bagaimana sekolah menyelesaikannya. (3) penelusuran dokumentasi untuk mengumpulkan data yang bersumber dari arsip dan dokumen yang ada di sekolah.

\section{Hasil Penelitian dan Pembahasan}

Penyelesaian Konflik di SMA Negeri 6 Yogyakarta

\section{Konflik Antar Peserta Didik}

Dengan adanya peraturan sistem rayonisasi dan pembatasan berdasarkan domisili orang tua, peserta didik SMA Negeri 6 berasal dari sekolah (SMP) dan daerah yang relatif homogen, yaitu sekitar kota Yogyakarta, atau asal daerah terjauh masih sebatas daerah propinsi Yogyakarta. Asal daerah yang relatif homogen menjadi salah satu variabel rendahnya tingkat konflik antar peserta didik dibandingkan 
dengan sekolah dengan peserta didik dengan daerah asal yang heterogen.

Pernyataan-pernyataan bahwa konflik di sekolah saat ini sudah kecil dan jarang terjadi, berbeda dengan beberapa tahun yang lalu merupakan salah satu usaha pencegahan sekolah terhadap munculnya kembali keadaan yang terjadi pada periode tahun 1995 - 2003. Para peserta didik menceritakan bahwa mereka sering mendapatkan cerita tentang bagaimana kondisi sekolah pada tahun-tahun itu dari para guru, karyawan, petugas keamanan.

Pada masa lalu, konflik dipahami sebagai sesuatu yang buruk, oleh karenanya harus disingkirkan. Pada saat ini, sudah dipahami bahwa konflik tidaklah baik atau buruk, melainkan konflik hanya tidak terhindarkan. Konflik merupakan bagian dari kehidupan yang tidak dapat dihindari atau dihindarkan.

Dengan demikian, konflik yang terjadi di SMA Negeri 6 pada saat ini, walaupun dinyatakan sangat kecil, tidak berarti tidak ada konflik. Konflik yang terjadi saat ini tetap ada dan dalam bentuk yang berbeda dari waktu-waktu sebelumnya. Konflik pada saat ini terjadi di antara peserta didik dalam bentuk saling mendiamkan, saling menjauhkan diri satu sama lain. Beberapa peserta didik mengatakan bahwa mereka akan diam dan tidak turut campur, cukup mengambil contoh mana yang baik dan mana yang buruk ketika terjadi konflik di antara teman-teman mereka.

Dalam prinsip resolusi konflik dan manajemen konflik berbasis sekolah (MKBS), cara penyelesaian konflik dengan mendiamkan dan menghindar, adalah cara yang tidak disarankan untuk diterapkan oleh peserta didik dan anggota organisasi sekolah yang lain. Urgensi MKBS adalah mengajarkan kepada peserta didik, guru dan semuanya bahwa konflik merupakan bagian alami dari kehidupan, dengan demikian juga bagian alami dari kehidupan di sekolah. Konflik akan selalu ada, tidak dapat dihindari atau dihindarkan, dengan demikian konflik harus dikenali dan dikelola (Pendharkar, 1995: 1).
Sekolah sebagai organisasi pendidikan sangat perlu mengajarkan keterampilan untuk mengenali dan mengelola konflik dengan baik. Sedangkan, perselisihan yang tidak diselesaikan ibarat api dalam sekam yang bisa membara menjadi perselisihan besar dalam bentuk perkelahian atau tawuran.

Keterampilan resolusi konflik antara lain adalah: bagaimana bertoleransi dan menghargai perbedaan pendapat atau persepsi, bagaimana menggunakan bahasa yang netral dan santun, bagaimana menjadi pendengar aktif, bagaimana mengidentifikasi masalah, bagaimana bernegosiasi dan bermediasi untuk menyelesaikan perselisihan. Pada jaman dan masyarakat yang semakin kompetitif, belajar menangani konflik secara konstruktif adalah keterampilan hidup yang diperlukan bagi peserta didik.

Sementara itu, penyelesaian konflik dengan cara menghindar disarankan untuk digunakan ketika tingkat hubungan diantara pihak yang berkonflik sangat lemah dan dalam tingkat hubungan yang bersifat win or lose. Tingkat hubungan yang lemah bisa dicontohkan dengan hubungan antara pembeli dan penjual. Dalam bernegosiasi, jika suatu harga yang ditawarkan oleh penjual tidak memenuhi standar tawaran pembeli, pembeli bisa dengan segera meninggalkan penjual. Sementara hubungan guru dan peserta didik, hubungan antar peserta didik (rekan satu sekolah) adalah hubungan jangka panjang, yang diharapkan selalu kuat dikarenakan mereka terikat dalam visi, misi dan tujuan yang sama (Johnson \& Johnson, 1995, p.37).

\section{Konflik Antar Kelompok Peserta Didik}

Konflik antar kelompok terjadi bisa berawal dari konflik antar individu yang tidak segera diselesaikan.

Konflik antar kelompok juga bisa disebabkan karena melencengnya niat baik awal pendirian kelompok. Asal mula berdirinya geng sekolah SMAN Negeri 6 yang bernama 'GNB', singkatan dari Gerakan Non Bojo adalah dari 'niat baik' tiga anak yang patah hati karena ada masalah 
dengan pacar. Kemudian tiga anak ini mengajak teman-teman yang lain untuk tidak pacaran selama sekolah dengan membentuk satu kelompok bersama. Tujuan mereka membentuk kelompok ini, untuk saling mengingatkan bahwa tugas utama bagi peserta didik adalah belajar, sehingga jika pacaran selama sekolah dan kebetulan putus cinta, kemungkinan besar akan menurunkan semangat dan konsentrasi belajar. Namun pada perkembangan selanjutnya, dengan semakin banyaknya anggota, tujuan kelompok melenceng dari tujuan pendirian awalnya.

Gootnick (Ivancevich, Konopaske \& Matteson, 2007, p.47) mengatakan bahwa terdapat tiga faktor penyebab konflik kelompok yaitu ketergantungan kerja, perbedaan tujuan dan perbedaan persepsi. Dengan semakin besarnya anggota kelompok, bisa dipastikan semakin besar pula perbedaan tujuan dan persepsinya. Sedangkan menurut hukum konflik antarorganisasi oleh Gootnick pula, setiap kelompok, kecil atau besar, pasti memiliki setidaknya konflik kecil atau besar dengan kelompok lain. Secara demikian, kelompok GNB ini pasti memiliki konflik dengan kelompok yang lain. Konflik mereka dipastikan terjadi dengan kelompok "tandingan", kelompok yang tidak cocok dengan cara-cara kekerasan mereka.

Mengapa konflik di sekolah ini terjadi dan berlangsung dalam waktu yang cukup lama (TA 1994/1995 hingga tahun TA 2003/2004)? Sepuluh tahun, sekolah dalam keadaan yang menegangkan, kekerasan kakak kelas terhadap adik kelas menjadi bagian dari kehidupan sehari-hari, guru dan pimpinan sekolah tidak berdaya, proses belajar mengajar berjalan tidak seperti yang diharapkan.

Pemahaman bahwa guru baru atau guru yang berusia muda serta belum memiliki jabatan sebagai pimpinan tidak memiliki kewenangan menegur, mengingatkan atau menghardik keras peserta didik yang melanggar peraturan, norma dan kesepakatan, dapat menghambat penyelesaian konflik yang terjadi di sekolah. Peran guru walaupun masih muda dan belum memiliki banyak pengalaman adalah sebagai pemimpin, moderator, pemberi ilmu dan role model yang patut untuk digugu (didengarkan) dan ditiru.

Mengapa para pimpinan sekolah juga mendiamkan? Para pimpinan menganggap "gojlokan" kakak kelas terhadap adik kelas dalam masa orientasi adalah hal yang biasa.

Dari sudut pandang MKBS, mengapa konflik di SMA Negeri 6 ini terjadi berkepanjangan dikarenakan konflik yang ada dalam kehidupan di sekolah ini belum dikenali dan belum dikelola. Demikian juga, adanya perbedaan persepsi dan tujuan antara beberapa guru dengan pimpinan menjadikan konflik di SMA Negeri 6 menjadi berkepanjangan. Salah satu komponen pembelajaran manajemen konflik adalah "bahwa pembelajaran manajemen konflik memerlukan tokoh sebagai model". Pendapat ini juga menjelaskan kondisi konflik di sekolah SMA Negeri 6 saat itu. Bahwa saat itu, sekolah belum memiliki tokoh yang bisa sebagai model bahwa guru pada prinsipnya memiliki kekuatan dan kewajiban untuk memimpin, menata dan menyelesaikan permasalahan di sekolahnya. Kondisi di SMA Negeri 6 berubah pada saat kehadiran Bapak Suradi, Kepala Sekolah baru pada tahun ajaran 2003/2004. Hingga saat ini beliau dipercaya sebagai tokoh perubahan dan pembaharuan dan tahun itu dianggap pula sebagai tonggak perubahan dan pembaharuan bagi SMA Negeri 6 Yogyakarta.

Beliau dianggap sebagai role model dan tokoh perubahan dan pembaharuan dikarenakan beliau sangat disiplin, 'pemberani', dan beliaulah yang berani 'memarahi' guru, memompa keberanian guruguru untuk bersikap tegas kepada para peserta didiknya, serta membangun komitmen dan sikap yang sama terhadap peserta didik. Beliau selalu mengingatkan kepada Bapak Ibu guru bahwa "semuanya dimulai dari kita" (para guru). Beliau juga yang berani merombak sistem dan segala hal yang mendukung perubahan. Antara lain, beliau melarang anak-anak menginap di sekolah atau pulang sekolah pada malam 
hari seperti yang terjadi pada waktu-waktu sebelumnya.

SMA Negeri 6 Yogyakarta memiliki tokoh perubahan selain Bapak Suradi, yaitu Bapak Sukarman. Pada 14 Januari tahun 2004 beliau diangkat menjadi wakil kepala urusan kesiswaan. Sejak itu, beliau melakukan banyak perubahan dan perombakan. Beberapa perombakan yang beliau lakukan adalah membuka komunikasi, berdialog dan bernegosiasi dengan peserta didik, seperti yang beliau sampaikan bahwa pernah terjadi pada suatu waktu beliau berdialog, bernegosiasi selama lima jam non-stop untuk menemukan persamaan pendapat dan tujuan dengan peserta didik.

Dalam usahanya menyelesaikan konflik antar kelompok, yaitu kelompok GNB dan kelompok-kelompok peserta didik lain. Beliau menciptakan konflik baru dengan membina OSIS sebagai kelompok tandingan GNB. Dengan menciptkan kekuatan tandingan ini, beliau berharap dapat melemahan kekuatan GNB.

Perombakan-perombakan lainnya yang dilakukan oleh Drs. Sukarman adalah, pertama, membangun kondisi kelas yang kondusif untuk pembelajaran dengan cara menghapus otonomi waktu secara bertahap. Pembatasan awal, peserta didik maksimal berada di sekolah sampai pukul 18 , selanjutnya sampai pukul 1730, berlanjut menjadi pukul 17 dan terakhir berlaku sampai saat ini, peserta didik terakhir berada di sekolah pukul 16.00. Satpam akan berkeliling sekolah 15 menit sebelum waktu berakhir, memeriksa apakah masih ada peserta didik yang tinggal di sekolah. Pada waktu-waktu sebelumnya, para peserta didik dibolehkan berada di sekolah tanpa batasan waktu dan tanpa pengawasan.

Kedua, mengganti beberapa kegiatan ekstra yang dinilai tidak mendukung proses pembelajaran dan memungkinkan menjadi sarana perekrutan geng sekolah dengan kegiatan lain. Sebagai contoh, sekolah meniadakan kegiatan peleton inti (tonti) dan mengganti dengan kegiatan siaga upacara. Sekolah juga meniadakan kegiatan malam pentas seni yang diseleng- garakan setelah kelulusan, dikarenakan malam pentas seni untuk kelulusan/ alumni bukan lagi menjadi tanggung jawab sekolah. Sekolah mengganti kegiatan Anniversary Live Music/ALM dengan Art Day dan Lomba Kreasi Seni. Untuk menyalurkan minat dan bakat serta untuk memberikan kegiatan yang bermanfaat, membuat empat belas pilihan program. Pada tahun 2005, sekolah merintis menjadi sekolah berbasis penelitian sosial dan sains yang berdasarkan kemanfaatan.

Satu perombakan mendasar lain yang sangat penting telah dilakukan oleh SMA Negeri 6 yaitu terbangunnya prinsip dan pemahaman bahwa guru harus mendampingi semua kegiatan peserta didik. Selain pemahaman itu, semua proses belajar mengajar adalah tanggung jawab sekolah dan guru, bukan tanggung jawab kakak kelas. Mereka mendapatkan pelajaran dari pengalaman bahwa tidak boleh ada kegiatan sekolah dimana peserta didik melatih sesama peserta didik. Hal itu akan menimbulkan penyimpangan-penyimpangan. Guru atau pendidik lah yang melatih dan mendampingi peserta didik.

\section{Konflik Peserta Didik dengan Guru/Sekolah}

Konflik yang terjadi di sekolah SMA Negeri 6, tidak hanya konflik diantara peserta didik, melainkan juga konflik antara peserta didik dan sekolah (guru). Konflik yang terjadi memiliki dampak negatif karena menguras waktu dan sumber daya organisasi, serta menghabiskan energi yang bisa digunakan untuk kegiatan yang konstruktif. Seperti diuraikan pada penjelasan di atas, bahwa konflik ini antara lain terjadi dikarenakan adanya perbedaan tujuan, perbedaan persepsi antara guru dan peserta didik, juga perbedaan persepsi diantara para guru sehingga mereka memiliki sikap dan kebijakan yang berbeda-beda terhadap peserta didiknya. Keadaan itu menjadi lebih buruk dengan belum adanya tokoh sebagai model pembelajaran manajemen resolusi konflik dan adanya rasa tidak berdaya dari para guru. 
Dalam manajemen resolusi konflik, sekolah perlu merancang proses belajar mengajar yang tidak terpaku pada keterampilan akademik saja. Selain keterampilan akademik, diperlukan juga keterampilan-keterampilan yang lain seperti keterampilan sosial dan keterampilan hidup. Dalam hal ini, guru sebagai pemimpin dan sebagai model pembelajaran bagi para peserta didik seyogyanya memiliki keterampilan sosial dan keterampilan hidup, juga memiliki kemampuan dasar seperti kemampuan orientasi, persepsi, emosi, berkomunikasi, berpikir kreatif dan berpikir kritis (Crawford, D. \& Bodine, R.,1996, p.11).

Namun dalam kenyataan, kemampuan ini terbatas pada ketidakmampuan guru karena tidak memiliki kewenangan untuk berpikir dan bertindak. Konflik yang terjadi antara guru dan peserta didik bisa terjadi dikarenakan para guru tidak satu visi dan adanya konflik personal atau kelompok diantara para guru itu sendiri. Pada kenyataannya anggota kesatuan sebuah lembaga atau organisasi penting untuk memiliki kesamaan persepsi dan tujuan. Dalam hal ini, guru sebagai anggota kesatuan organisasi sekolah perlu memiliki persamaan persepsi, tujuan, visi, misi.

Penyelesaian Konflik di SMA Kolese de Britto Yogyakarta

\section{Antar Peserta Didik dan Antar Kelompok Peserta Didik}

Dalam sub-bab ini, peneliti menggabungkan penjabaran tentang penyelesaian konflik antar (invidu) peserta didik dengan antar kelompok peserta didik. Penjelasannya adalah bahwa Sekolah SMA Kolese de Britto menyelesaikan kedua bentuk konflik tersebut dalam programprogram yang sudah dirancang oleh sekolah. Konflik-konflik yang terjadi dalam kehidupan belajar dan pembelajaran sehari-hari dikenali dan diselesaikan sesuai kriteria konfliknya masing-masing. Penyelesaian konflik menggunakan programprogram kegiatan yang dirancang secara kondusif untuk mengenali dan menyelesai- kan konflik, pada tujuan akhirnya untuk mendukung kelancaran proses kegiatan belajar mengajar.

Program-program itu adalah: pertama, program inisiasi atau masa orientasi siswa. Program inisiasi adalah program pengenalan visi-misi sekolah dan pemahaman logika-logika dasar. Sejak tahun 1992, penanggungjawab dan pengisi materi program ini adalah guru, bukan kakak kelas. Kakak kelas berperan sebagai asisten guru. Penjelasannya adalah bahwa kakak kelas bukan pelaksana program pendidikan dan bukan penanggungjawab pendidikan. Sementara program inisiasi atau MOS itu adalah program yang sangat penting, karena melalui program itulah anak didik untuk pertama kali diperkenalkan tentang visi dan misi sekolah. Para peserta didik baru ibaratnya adalah "lembaran kosong yang perlu diisi dengan goresan awal yang jelas dan tegas". Sehingga apapun yang diperkenalkan di momen ini, biasanya sangat mudah diingat dan mudah diserap.

Masa inisiasi adalah masa yang paling tepat untuk penanaman nilai-nilai yang mendasar. Sekolah dapat memanfaatkan kesempatan masa inisiasi (MOS) untuk mendapatkan pengalaman-pengalaman dan masukan-masukan tentang 'pembongkaran' pemikiran dan penanaman nilainilai dasar kepada peserta didik. Dengan demikian, guru harus tegas dan jelas pada proses penanaman nilai-nilai dasar.

Belajar dari pengalaman-pengalaman sebelumnya, dimana seringkali program MOS menjadi konflik yang tidak menguntungkan (dysfungtional conflict) bagi lembaga sekolah dan proses pendidikannya. Hal tersebut dikarenakan program MOS dipercayakan kepada kakak kelas sebagai senior pendamping dan pemberi materi pembelajaran kepada adik kelas peserta didik baru. Oleh karenanya, sejak tahun 1992 SMA Kolese de Britto mengambil keputusan bahwa guru yang memiliki lisensi untuk mendidik, bukan peserta didik. Sehingga dalam masa inisiasi atau MOS, guru yang menjadi pembimbing utama semua prosesnya. Demikian juga, dalam acara dan kegiatan sekolah apapun, 
harus ada guru sebagai pendamping acaranya. Konflik yang terjadi pada peserta didik biasanya adalah jika terdapat sistem senioritas diantara para peserta didik dan biasanya tanpa adanya pendampingan guru.

Masa inisiasi juga merupakan saatsaat yang penting untuk mengajarkan pelajaran tentang perdamaian dan pelajaran yang tampak kecil tapi sangat penting. Pelajaran pertama bagi peserta didik adalah menyapa, satu pendidikan wajib yang harus diamalkan. Peserta didik diwajibkan menyapa siapa saja, menyapa teman, kakak kelas, guru, tamu dan siapapun yang ditemui dan dilewati.

Logika-logika dasar yang diajarkan pada momentum ini, antara lain peserta didik diberikan pemahaman bahwa mereka harus pintar, sehat dan kuat dulu, sebelum mereka menolong dan bermanfaat bagi orang lain. Sekolah juga mengajarkan pada peserta didik tentang hal-hal penting mendasar seperti mengapa penting dan perlunya anak-anak makan sarapan. Dengan penjelasan bahwa kita memerlukan enerji untuk tumbuh dan berkembang, untuk menjalankan tugas dan untuk tumbuh menjadi baik dan menjadi pintar. Walaupun kita pintar, namun kalau kita lemah dan sakit-sakitan, itu akan menjadi beban dan masalah bagi orang lain. Artinya, kuatkan diri kita sendiri dulu sebelum menguatkan orang lain. Sarapan dalam hal ini sangat penting untuk menjaga kesehatan.

Pada masa inisiasi ini juga diajarkan pemahaman tentang pentingnya menjaga pola hidup dan pola makan sehat. Pelajaran yang diajarkan, antara lain, para peserta didik diajarkan agar minum cukup. Pelajaran ini dipahami dan dipraktekkan oleh peserta didik, tampak dari pengamatan bahwa para peserta didik membawa botol dan mengisi botol minumannya dari galon-galon air mineral yang disediakan di sudut-sudut selasar sekolah.

Pelajaran dasar yang lain adalah tentang pola makan 'empat sehat lima sempurna'. Kita makan harus bervariasi dan lengkap, tidak bisa jika hanya minum susu saja. Susu dalam pola makanan "empat sehat lima sepurna' adalah sebagai penyempurna. Jika kita hanya minum susu, pertanyaannya kemudian adalah apa yang akan kita sempurnakan jika empat unsur yang lain belum kita penuhi atau belum kita makan?

Contoh-contoh lain pembelajaran logika dasar ketika masa inisiasi adalah, pembelajaran bahwa 'hidup adalah pilihan'. Sejak awal para peserta didik diperkenalkan bahwa mereka akan menjadi pemalas, berambut gondrong, gundul, pintar, rajin, sukses, gagal adalah pilihan, dan dalam setiap pilihan-pilihan itu mengandung resiko dan konsekuensi. Sebagai misal adalah pilihan bersekolah menjadi peserta didik di SMA Kolese de Britto, itu juga sebuah pilihan. Di dalam pilihan itu mengandung konsekuensi bahwa menjadi peserta didik SMA Kolese de Britto harus satu visi dan misi dengan sekolahnya. Jika visinya tidak sama, lebih baik mengundurkan diri saja. Mengapa demikian? Jika mereka tetap berada di SMA de Britto namun tidak satu visi, pasti merasa tidak nyaman, tidak optimal, dan sebagainya. Sekolah juga mengajak anak-anak ke lapas (lembaga pemasyarakatan) untuk memperkenalkan bahwa ada resiko dari segala keputusan dan tindakan.

Pembelajaran tentang pilihan dan konsekuensi merupakan bagian dari penerapan pembelajaran resolusi konflik. Jika setiap individu dalam memutuskan suatu pilihan dan dia memahami bahwa ada konsekuensi serta resikonya, dipastikan konflik akan mudah dikelola dan diselesaikan. Pendidikan mengajarkan pembuatan keputusan atau pilihan dengan mengenali segala konsekuensi-konsekuensi dari pilihan-pilihan. Dengan demikian, asumsinya bahwa proses dan tahapan resolusi konflik lebih mudah untuk dilaksanakan di lembaga pendidikan dan kepada kelompok-kelompok anggota masyarakat yang berpendidikan.

SMA Kolese de Britto dikenal sebagai sekolah yang memberikan kebebasan kepada peserta didiknya. Sebagai contoh, peserta didik dibebaskan untuk berambut gondrong, tidak mengenakan seragam 
putih abu-abu, sepatu boleh diinjak bagian belakangnya, boleh memakai sepatu sandal dan memakai kaos (berkrah). Dalam kerangka pikir manajemen resolusi konflik tentang kebijakan kebebasan yang diterapkan di SMA Kolese de Britto ini, kebijakan ini merupakan pembelajaran tentang toleransi dan penghargaan terhadap perbedaan. Perbedaan-perbedaan fisik, karakter, pendapat, kebiasaan, persepsi, tujuan yang dimiliki dan dipahami oleh masing-masing individu akan menjadi bagian dari kehidupan yang diterima secara wajar. Konflik-konflik yang muncul sebagai konsekuensi dari segala perbedaan yang ada akan diterima secara wajar dan alami juga.

SMA Kolese de Britto memberikan pengarahan dan bimbingan kepada peserta didik bahwa hidup adalah pilihan, dan setiap pilihan mengandung konsekuensi. Bahwa anak-anak memilih untuk berambut gondrong, itu adalah pilihan. Bahwa nanti rambutnya akan dikepang atau bau itu adalah ekses (konsekuensi negatif) dari kebijakan diijinkannya berambut panjang. Bahwa anak-anak kalau memakai sepatu diinjak bagian belakangnya adalah ekses dari diijinkan memakai sepatu sandal. Demikian juga kalau anak-anak memakai celana jeans itu adalah ekses dari tidak mengenakan seragam. Sekolah juga memiliki ekses-ekses (konsekuensi-konsekuensi negatif) dari kebijakan yang diputuskan. Namun, sekolah menyadari bahwa segala konsekuensi harus dikenali dan dikelola. Sekolah perlu selalu mengajarkan dan mendidik terus kepada peserta didik mengelola dan mengurangi konsekuensikonsekuensi negatif itu. SMA Kolese de Britto sebagai lembaga pendidikan mengambil pilihan bahwa sekolah tidak selayaknya memikirkan cara-cara untuk menghilangkan konsekuensi-konskuensi negatif itu. Misalnya, dengan cara antara lain peserta didik diwajibkan berseragam dan berambut cepak. Pemikiran seperti ini adalah pemikiran yang mengaburkan prinsip penghargaan terhadap perbedaan dan keberagaman yang sangat mendasar. Sementara pendidikan itu adalah sebuah proses berpikir untuk mengajarkan agar selalu mengurangi dampak-dampak dan konsekuensi-konsekuensi negatif dari pilihanpilihan atau keputusan-keputusan yang diambil.

Sekolah juga mengajarkan pemahaman kepada peserta didik bahwa bebas itu adalah "bebas untuk" bukan "bebas dari". Kebebasan yang diberikan kepada peserta didik itu berdasarkan pemahaman bahwa "dengan kebebasan, manusia bebas dari beraneka ragam alienasi yang menekannya, dan bebas pula untuk kehidupan yang utuh, tak tercela, berdiri dan kreatif" (Setyadi, 2009, p.16) Sedangkan pengertian "bebas dari" adalah bebas dari ancaman, bebas dari penindasan, bebas dari rasa takut. Pemahaman ini dijelaskan dengan pembelajaran bahwa Tuhan menciptakan manusia sebagai makhluk yang bebas, merdeka, jauh dari segala ancaman dan ketakutan. Dengan demikian, tidak sepantasnya bahwa manusia memiliki rasa "bebas dari", yang ada seharusnya adalah "bebas untuk melangsungkan kehidupan secara bebas, merdeka dan jauh dari segala ancaman dan ketakutan.".

Nilai-nilai kebebasan yang diajarkan oleh sekolah sudah dipahami oleh peserta didik dengan kesadaran bahwa mereka bebas untuk belajar apa saja, asal sesuai dengan ketentuan norma-norma yang berlaku. Nilai-nilai yang diajarkan oleh sekolah menjadikan para peserta didik secara lebih ringan menyelesaikan konflik yang terjadi di antara mereka, juga konflik dengan guru atau sekolah.

Program kedua adalah malam keakraban yang lebih sering disebut dengan "makrab". Sejak tahun 1993, makrab diselenggarakan satu tahun sekali, setiap awal tahun ajaran. Program ini wajib diikuti oleh setiap peserta didik kelas $X$ dengan pengisi program dan pendampingnya adalah para guru. Program ini biasanya diselenggarakan pada pertengahan semester pertama (sekitar bulan September-Oktober). Program ini diselenggarakan bergilir perkelas, diselenggarakan sejak sabtu siang hingga minggu siang, bertempat di luar sekolah. Pada malam ini, dibuat semacam permainan-permainan 
yang mengakrabkan setiap anak dan guru. Pada malam itu, anak-anak diminta membuat komitmen bersama untuk kebaikan kelas satu tahun ke depan. Dengan demikian, pada hari-hari selanjutnya guru lebih mudah dalam mengingatkan anak-anak dikarenakan mereka telah membuat komitmen-komitmen dari dan untuk mereka sendiri.

Pada malam keakraban itu, peserta didik juga dibebaskan untuk menyampaikan keluhan, pendapat, komitmen, masukan dan kritikannya kepada sesama teman juga kepada guru. Materi yang diajarkan pada malam keakraban pada intinya adalah bagaimana setiap individu menghargai perbedaan, bagaimana berlapang dada, tidak mudah sakit hati jika menerima masukan dan kritikan, serta bagaimana mengungkapkan perasaan hati yang tidak senang dan tertekan karena ketidakcocokan dengan teman atau guru. Mereka juga mendiskusikan bagaimana sebaiknya menyelesaikan masalah-malasah itu.

Komitmen-komitmen bersama yang mereka buat misalnya sebagai berikut: jangan suka bergerombol, jangan berteman dengan teman yang itu-itu saja, jangan suka bicara keras dan kasar, dan sebagainya. Dengan malam keakraban ini, konflik kelas $X$ yang lebih bersifat antar pribadi, menjadi sesuatu hal yang lebih bisa diterima. Masing-masing anak menjadi belajar untuk menghargai perbedaan.

Program ketiga, dinamakan "jam perwalian". Jam perwalian ini diadakan satu jam setiap satu minggu sekali, diatur oleh sekolah dan diadakan serempak sesuai kesepakatan bahwa semua wali kelas ada di sekolah pada jam itu. Pada jam perwalian, yang diadakan sejak tahun 2002 ini, para wali kelas selama 1 jam (60 menit) mengajak semua warga kelas membuka diri jika ada yang perlu dibahas dan dibicarakan, baik masalah sekolah maupun masalah pribadi. Setiap peserta didik memiliki haknya. Jika pada saat itu, ada peserta didik yang ingin konsultasi masalah pribadi, wali kelas akan memberikan tugas kepada peserta didik yang lain dan memberikan waktunya untuk berbicang secara khusus dengan peserta didik yang bersangkutan. Peserta didik yang tidak mendapatkan kesempatan dalam minggu ini, mereka bisa menyampaikan pada minggu-minggu berikutnya atau jika mendesak, mereka bisa meminta waktu khusus kepada wali kelasnya. Jika tidak ada peserta didik yang ingin berkonsultasi masalah pribadi, wali kelas menyampaikan materi kekinian yang dirasakan perlu menjadi pembahasan bersama.

Pada jam perwalian ini, tetap berlaku peraturan bahwa semua peserta didik tetap berada di dalam kelas. Jika makrab yang dilaksanakan satu tahun sekali, dirasa cukup membantu mengenalkan para peserta didik satu sama lain, mengakrabkan dan mengenalkan kepada keberagaman dan perbedaan, maka jam perwalian yang diselenggarakan setiap minggu menjadikan konflik dan permasalahan yang muncul segera dapat terselesaikan. Bahwa memang sebaiknya permasalahan tidak harus ditunggu besar baru akan diselesaikan.

Peserta didik perlu dibekali pengetahuan untuk dapat menyelesaikan permasalahan yang mengena kepada mereka. Bekal pengetahuan itu antara lain tentang pemahaman permasalahan kehidupan sehari-hari, penggunaan media sosial, penggunaan kecanggihan teknologi elektronik secara benar, bagaimana menjadi pengguna jalan raya yang baik, serta bagaimana berperilaku dan bertutur kata yang santun dan sopan. Pada permasalahan-permasalahan ini, sekolah memanggil ahlinya untuk menjelaskan dan memahamkan langsung kepada seluruh peserta didik. Sebagai misal, untuk masalah penggunaan kendaraan dan jalan raya, sekolah mendatangkan petugas dari kepolisian untuk memberikan penjelasan dan berdiskusi bersama.

Program yang lain adalah program yang mengantisipasi kemungkinan konflik dengan orang tua peserta didik. Tidak dapat dipungkiri bahwa orang tua bisa memprotes sekolah jika puteranya terkena keputusan atau tindakan yang dianggap merugikan, seperti mendapat hukuman, 
skorsing atau tidak naik kelas. Dalam hal ini sekolah membuat perjanjian kontrak kerjasama dan kesepakatan dengan orang tua sejak awal tahun masuk sekolah. Perjanjian itu berisi kesepakatan dari para orang tua untuk mengikuti visi, misi dan tujuan sekolah. sehingga, jika terjadi demikian, sekolah mengembalikan kepada kontrak perjanjian awal ketika memasuki sekolah, bagaimana kesanggupan dan komitmen para orang tua terhadap segala aturan dan visi yang berlaku di sekolah.

Kewajiban mendidik anak adalah menjadi tanggung jawab bersama antara sekolah dengan orang tua. Guru SMA Kolese de Britto akan meminta kehadiran orang tua untuk datang ke sekolah, jika ada permasalahan yang perlu diselesaikan bersama. Jika komunikasi sekolah dan orang tua berlangsung baik, diharapkan keadaan anak di rumah atau di sekolah sama-sama diketahui oleh orang tua dan oleh sekolah. Anak bisa saja bersikap sangat manis ketika berada di rumah, di sekolah bersikap sebaliknya. Demikian juga sebaliknya, di rumah bersikap kurang baik, di sekolah baik sekali.

Keempat program di atas adalah program wajib yang harus diikuti oleh semua civitas akademika (guru, peserta didik, orang tua). Dengan program-programnya, sekolah Kolese de Britto mengenalkan kepada seluruh civitas akademika bahwa konflik adalah bagian dari kehidupan sehari-hari, yang selalu ada, tidak bisa dihindari. Demikian juga, konflik tidak boleh dimatikan, harus dihadapi dan diselesaikan.

\section{Konflik Peserta Didik dengan Guru/Sekolah}

Malam keakraban, jam perwalian, pertemuan waktu khusus secara personal antara peserta didik dan guru, komunikasi melalui surat tertulis kepada guru, menjadi sarana penyelesaian konflik antara sesama peserta didik, juga antara guru dan peserta didik. Program-program tersebut bertujuan untuk membangun persepsi dan tujuan yang sama, serta membangun komunikasi yang akrab dan terbuka antara guru dan peserta didik. Hubungan guru dan peserta didik sangat perlu dibangun keakraban dan komunikasi yang terbuka satu sama lain.

Sekolah melalui guru-guru selalu mengingatkan persamaan visi sebagai satu keluarga besar "SMA Kolese de Britto", serta menerapkan komunikasi yang akrab dan terbuka antara guru dan peserta didik. Dengan demikian peserta didik merasa mudah dan nyaman menyampaikan segala permasalahannya tanpa merasa takut dan tertekan. Peserta didik diperbolehkan mengeluhkan segala permasalahannya tentang sekolah, keluarga, teman atau pacar kepada guru bahkan kepada kepala sekolah secara langsung di ruang kepala sekolah.

Untuk membangun sebuah budaya sekolah yang kritis dan lugas seperti digambarkan sebelumnya, perlu perjuangan dari semua insan di dalam organisasi sekolah secara bersama-sama dan terus menerus. Perjuangan itu antara lain seperti kesiapan menerima kritikan langsung dengan lapang dada. Sebagai contoh, bahwa guru harus berlapang dada dan berterima kasih ketika peserta didik mengingatkan untuk tidak duduk di meja atau ketika menerangkan terlalu cepat, tulisan tidak jelas. Peserta didik menjadi kritis dan lugas adalah hasil dari pembelajaran yang diberikan oleh guru. Keadaan seperti ini disadari sepenuhnya oleh para guru.

Pernah terjadi perbedaan pendapat diantara para guru tentang demo protes dari peserta didik kepada sekolah. Protes peserta didik menjadi pembahasan di forum guru. Sebagian guru menanggapi dengan menanyakan "siapa yang ada di belakang mereka?". Sebagian yang lain menyatakan bahwa sekolah tidak perlu mencari siapa pendukung demo dan siapa yang dibelakang protes peserta didik. Hal yang sangat perlu diperhatikan oleh sekolah adalah apa yang dikehendaki oleh para peserta didik, apa tujuan dan esensi dari protes ini, serta mengevaluasi diri mengapa peserta didik menyampaikan aspirasi, kritikan dan kehendak mereka dengan cara demo protes dan menempelkan kertas di banyak tempat. Peserta didik 
harus tetap mendapat perhatian, karena mereka sudah menyampaikan kritik, pendapat, keinginan dan persepsi mereka. Sejak pertama kali mereka datang ke sekolah, mereka diajarkan untuk selalu bebas berpendapat, kritis dan berani mengungkapkan pendapat. Dengan demikian, ketika mereka menemukan masalah dan berani mengungkapkan masalahnya dan kritik terhadap guru atau sekolah, sudah seharusnya guru atau sekolah tidak boleh menghindar. Jika cara yang mereka lakukan dengan protes dan menempelkan kertas di banyak tempat, itu adalah cara yang kurang benar, tidak sopan, maka menjadi kewajiban sekolah dan guru untuk mengajarkan kepada peserta didik bagaimana menyampaikan pendapat, kritikan dan aspirasi dengan cara yang sopan dan santun.

Secara prinsip, guru adalah pendidik bagi anak didiknya. Guru sebaiknya memiliki enam kemampuan dasar resolusi konflik, yaitu kemampuan berorientasi, persepsi, mengendalikan emosi, berkomunikasi, berpikir kreatif dan berpikir kritis. Jika para guru memiliki kemampuankemampuan dasar resolusi konflik ini, bisa diharapkan bahwa para peserta didik juga akan memiliki kemampuan ini.

Kemampuan dasar ini ditransferkan kepada para peserta didik melalui sikap dan dalam jawaban-jawaban terhadap pertanyaan kritis peserta didik. Pertanyaannya adalah "mengapa dia dan temannya tidak boleh merokok, padahal guru-guru ada yang merokok?". Tanggapan seorang guru senior seperti yang dikisahkan berikut.

“...Sampai di sini saya cukup tersentak. Kalau kita tidak memiliki pengalaman dan wawasan yang luas, tidak mudah menjawab yang memberikan pemahaman sekaligus pencerahan kepada anak-anak. Jawaban saya: "mas, de Britto ini ibarat masyarakat kecil yang memiliki aturan dan hukum sendiri, sehingga apa yang terjadi di sini berlaku sesuai dengan aturan dan hukumannya sendiri. Jadi, tidak usah mengurusi segala hal yang bukan urusan dan kewenangan kita". Saya melanjutkan dengan penjelasan; "untuk lebih jelasnya, segala urusan dan masalah di kabupaten Sleman diselesaikan dengan hakim, jaksa, dan polisi Sleman, bukan diselesaikan oleh polisi, hakim atau Jaksa di Jakarta". "Di de Britto ini, urusan siswa adalah dengan saya (bagian disiplin), sedangkan urusan guru adalah urusan kepala sekolah dan yayasan. Kalau kamu tidak puas dengan kepala sekolahmu, lapor yayasanmu. Kalau kamu tidak puas dengan gurumu, lapor kepada kepala sekolahmu. Urusanmu saat ini adalah dengan saya, urusan guru adalah urusan kepala sekolah. Tidak usah melebarkan urusan kemana-mana". Pada kesempatan ini saya sekaligus memahamkan kepada mereka tentang hukum ketatanegaraan, yang tentunya akan mereka gunakan sampai kapan pun.

\section{Simpulan dan Saran}

Simpulan

Konflik antara peserta didik dalam tindakan saling mendiamkan dan tidak saling menolong. Konflik dalam skala yang lebih tinggi diantara mereka, bisa berwujud dalam tindakan perkelahian dan kekerasan.

Konflik pribadi/individual yang tidak diselesaikan, cepat atau lambat akan mengganggu bagi peserta didik yang bersangkutan. Sebagai anggota sebuah organisasi sekolah, performa peserta didik dalam keadaan konflik akan mengganggu dirinya dan kelompoknya. Sementara itu, konflik antara kelompok, biasanya dimulai dari permasalahan individual yang tidak diselesaikan dan kemudian berkembang menjadi konflik antar kelompok.

Konflik guru dan peserta didik bisa terwujud dengan sikap peserta didik yang tidak sopan terhadap guru, mengabaikan penjelasan dan pelajaran dari guru, mengganggu kelancaran kerja guru, tidak mengikuti kelas, tidak masuk sekolah, hingga mengancam guru.

Konflik guru dan peserta didik, lebih dimungkinkan karena ketidaksiapan guru menerima kekritisan dan kelugasan peserta didik. Kemungkinan lain karena ketidaksamaan persepsi dan tujuan/target yang tajam antara guru dan peserta didik. 
Sekolah menyelesaikan konflik peserta didik (individu dan kelompok) dengan beberapa strategi dan cara. Strategi dan cara yang dipilih ditentukan oleh bentuk konflik, latar belakang konflik dan tingkat kedalaman konflik yang terjadi. Sebagai contoh: konflik diselesaikan dengan cara mendatangkan tokoh yang kuat dari peserta didik atau guru, membentuk kelompok/konflik tandingan untuk menundukkan kelompok yang bermasalah, memberikan pemahaman nilai dasar kehidupan, membangun komitmen, keakraban dan keterbukaan.

Guru adalah ujung tombak lembaga sekolah. Konflik peserta didik dengan guru, bisa diasumsikan konflik peserta didik dengan sekolah. Untuk menyelesaikan konflik ini, sekolah perlu membangun visi dan misi yang sama, serta keakraban melalui berbagai program kegiatan.

\section{Saran}

Sekolah adalah agen perubahan, pembaharuan, pencetak generasi masa depan. Sekolah adalah sebuah masyarakat kecil sebagai "tempat pelatihan atau magang" bagi peserta didik untuk mempelajari banyak hal tentang kehidupan. Pada masanya nanti akan dipraktekkan dalam kehidupan nyata. Konflik adalah bagian alami dari kehidupan, maka dari itu konflik juga merupakan bagian alami dari kehidupan sekolah. Belajar untuk menangani konflik secara konstruktif adalah keterampilan hidup yang diperlukan oleh peserta didik.

Sekolah perlu menciptakan konflik secara sengaja untuk membangun kompetisi bersaing dalam kebaikan, serta membangun semangat pembaharuan dalam tubuh organisasinya.

Guru sebagai manusia dewasa dan tokoh dalam masyarakat sekolah sangat perlu mendapat pelatihan kepemimpinan dan pelatihan kemampuan dasar resolusi konflik. Guru tidak boleh merasa tidak berdaya (powerless) terhadap peserta didiknya sendiri. Pepatah (Jawa) bahwa guru sebagai yang digugu dan ditiru tetap harus berlaku sepanjang jaman.
Guru sebagai pengganti orang tua di sekolah perlu memiliki ketegasan dalam menyampaikan nilai-nilai dan kebenaran. Guru perlu membangun keterbukaan dan keakraban dengan peserta didik, agar peserta didik merasa nyaman dan senang berada di sekolah. Jika para guru sebagai manusia dewasa dalam masyarakat sekolah bersikap baik dan menyenangkan, peserta didik akan merasa sekolah menjadi rumah kedua yang nyaman dan aman untuk mempelajari banyak hal.

\section{Daftar Pustaka}

Chatib, M. (2009). Sekolahnya manusia: sekolah berbasis multiple intelligences di Indonesia. Bandung: PT. Mizan Pustaka.

Crawford, D. \& Bodine, R. (1996). Conflict resolution education: a guide to implementing programs in schools, youth-serving organizations, and community and juvenile justice settings. (Program Report). US Department of Justice \& US Department of Education.

Deutsch, M., Coleman, P.T., \& Marcus, E.C. (Eds). (2006), The handbook of conflict resolution: theory and practice. San Francisco, CA: Jossey-Bass

Ivancevich, J. M., Konopaske, R., \& Matteson, M. T. (2007). Perilaku dan manajemen organisasi. (Terjemahan Dharma Yuwono, S.Pd.). The McGraw-Hill Companies: USA. (Buku asli diterbitkan tahun 2005edisi ketujuh).

Johnson, D.W., \& Johnson, R.T. (1940). Reducing school violence through conflict resolution. Alexandria, Virgina: Association For Supervision and Curriculum Development (ASCD).

Panggabean, R. (2 Juni 2008). Manajemen konflik berbasis sekolah, Media Indonesia, p.5.

Pendharkar, M. (1995). School-based conflict management. SSTA Research Centre

Setyadi, W. S. J. F. (2009). Menjadi manusia bebas: refleksi tentang pendidikan bebas di SMA Kolese de Britto. Yogyakarta: Penerbit Kanisius. 